\title{
Orexin-A stimulates $3 \beta$-hydroxysteroid dehydrogenase expression and cortisol production in H295R human adrenocortical cells through the AKT pathway
}

\author{
XIAOCEN CHANG, YUYAN ZHAO, SHUJING JU and LEI GUO \\ Departments of Endocrinology and Orthopedic Surgery, The First Affiliated Hospital, \\ China Medical University, Shenyang, Liaoning 110001, P.R. China \\ Received April 17, 2014; Accepted September 23, 2014
}

DOI: 10.3892/ijmm.2014.1959

\begin{abstract}
Orexin-A is a regulatory peptide involved in the regulation of food intake, sleep-wakefulness, and it has various endocrine and metabolic functions. It orchestrates diverse central and peripheral processes through the stimulation of two G-protein coupled receptors, orexin receptor type 1 $\left(\mathrm{OX}_{1}\right.$ receptor) and orexin receptor type 2 ( $\mathrm{OX}_{2}$ receptor). In this study, human adrenocortical cells (NCI-H295R cells) were incubated with various concentrations of orexin-A $\left(10^{-10}\right.$ to $\left.10^{-6} \mathrm{M}\right)$ in vitro, and the mRNA and protein expression of $\mathrm{OX}_{1}$ receptor was determined in the cells. In addition, NCI-H295R cells treated with $10^{-6} \mathrm{M}$ orexin-A were then treated with or without $\mathrm{OX}_{1}$ receptor specific antagonist (SB334867), AKT antagonist (PF-04691502), or a combination of both. Subsequently, cell proliferation, the cortisol content in the medium and the mRNA and protein expression expression of $3 \beta$-hydroxysteroid dehydrogenase ( $3 \beta$-HSD) were analyzed. The activity of the AKT signaling pathway was also determined in the NCI-H295R cells. We observed that the increase in the mRNA and protein expression of $\mathrm{OX}_{1}$ receptor was orexin-A concentration-dependent, with $10^{-6} \mathrm{M}$ orexin-A exerting the most potent effect. Orexin-A enhanced cell proliferation and cortisol production, and increased the mRNA and protein expression of 33-HSD in the NCI-H295R cells; however, these effects were partly blocked by the $\mathrm{OX}_{1}$ receptor antagonist, the AKT antagonist and the combination of both. Furthermore, orexin-A significantly increased the phosphorylation of AKT,
\end{abstract}

Correspondence to: Professor Yuyan Zhao, Department of Endocrinology, The First Affiliated Hospital, China Medical University, Shenyang, Liaoning 110001, P.R. China

E-mail: g572@sina.com

Abbreviations: $\mathrm{OX}_{1}$ receptor, orexin receptor type $1 ; \mathrm{OX}_{2}$ receptor, orexin receptor type 2; AKT/PKB, protein kinase B; MAPK, mitogenactivated protein kinase; PI3K, phosphatidylinositol 3-kinase; PKA, protein kinase $\mathrm{A} ; \mathrm{PKC}$, protein kinase $\mathrm{C} ; 3 \beta$-HSD, $3 \beta$-hydroxysteroid dehydrogenase

Key words: orexin-A, orexin receptor type 1, cortisol, AKT signaling pathway, $3 \beta$-hydroxysteroid dehydrogenase, adrenocortical cells with the levels of total AKT protein remaining unaltered. This effect was blocked in the presence of PF-04691502 $\left(10^{-6} \mathrm{M}\right)$, SB334867 $\left(10^{-6} \mathrm{M}\right)$ and the combination of both. On the whole, our data demonstrate that the effects of orexin-A on the survival and function of human adrenocortical cells are mediated through the AKT signaling pathway.

\section{Introduction}

Orexin-A and orexin-B, also known as hypocretin-1 and hypocretin-2, have been implicated in a wide range of central, as well as peripheral functions (1-4). Orexins were initially characterized as neuropeptides restricted to hypothalamic neurons in the brain that projected to nuclei involved in the control of food intake, sleep-wakefulness, neuroendocrine homeostasis and autonomic regulation (5). The functions of orexins are mediated by two membrane bound G-protein coupled receptors, the orexin receptor type $1\left(\mathrm{OX}_{1}\right.$ receptor) and the orexin receptor type $2\left(\mathrm{OX}_{2}\right.$ receptor). While both peptides bind with almost equal affinity to the $\mathrm{OX}_{2}$ receptor, the $\mathrm{OX}_{1}$ receptor seems to be selective for orexin-A (4). Further observations have indicated that orexins and their receptors are not restricted to the hypothalamus, but are also expressed in a few peripheral tissues (5), including the adrenal glands, gastrointestinal tract and the pancreas (4). To date, compelling evidence indicates an interaction of the orexin system with the hypothalamuspituitary-adrenal (HPA) axis on a central, as well as peripheral level (6). Orexins $\left(10^{-10}\right.$ to $\left.10^{-6} \mathrm{M}\right)$ exert a stimulatory effect on glucocorticoid release, adrenocortical cell growth and, in some cases, mineralocorticoid release from the adrenal cortex of various species (7-13). This fact seems to be related to orexin-A $\left(10^{-6} \mathrm{M}\right)$ enhancing the expression of $3 \beta$-hydroxysteroid dehydrogenase (3 $\beta$-HSD) (14). The enzymes of the $3 \beta$-HSD family that catalyze the conversion of $\Delta^{5}-3 \beta$-hydroxysteroids into $\Delta^{4}$-3-ketosteroids are located in the endoplasmic reticulum and the mitochondrial membrane (14-17). Thus, $3 \beta$-HSD plays a key role in glucocorticoid synthesis and is expressed in a number of tissues, including the adrenal glands, gonads and the brain (17). Wenzel et al (14) found that orexins stimulated glucocorticoid secretion from human adrenocortical NCI-H295R cells, and that this increase was accompanied by a simultaneous increase in the mRNA levels of $3 \beta$-HSD. However, little is known 
regarding the mechanisms involved in the effects of orexins leading to an increased level of $3 \beta$-HSD in adrenal cells.

AKT, also known as protein kinase B (PKB), is essential for cell survival and growth during development and carcinogenesis. AKT is a serine-threonine kinase that is regulated mainly following the activation of the second messenger, phosphatidylinositol 3-kinase (PI3K). Abundant evidence indicates that $\mathrm{AKT}$ is a key regulator of multiple cell survival mechanisms (18-24). AKT was first characterized for its function in regulating cell proliferation and survival, which may be due to the direct or indirect effects of AKT on a number of cellular proteins. For example, AKT phosphorylates and activates mammalian target of rapamycin (mTOR) in response to growth factors and oncogenes (19-21). As such, AKT plays key roles in cell survival (22), cell proliferation (23), cell growth (24) and apoptosis (22). To date, certain studies have indicated the involvement of orexins in the regulation of cell viability, cell proliferation and cortisol production $(25,26)$. These effects can be mediated through multiple signaling pathways, including protein kinase $\mathrm{A}$ (PKA), protein kinase $\mathrm{C}$ (PKC) and mitogen-activated protein kinase (MAPK) cascade-dependent mechanisms $(14,25,26)$. However, little is known of the ability of orexins to activate the PKB/AKT pathway in adrenal cells.

In the present study, human NCI-H295R cells were used as an adrenocortical cell model (27). The cells were exposed to various concentrations of orexin-A $\left(10^{-10}\right.$ to $\left.10^{-6} \mathrm{M}\right)$, in the presence of $\mathrm{OX}_{1}$ receptor antagonist, AKT antagonist or a combination of both, and cell proliferation assays were then performed to assess the effects of orexin-A on adrenocortical cell growth. Our results revealed that orexin-A significantly enhanced the expression of $3 \beta$-HSD and the production of cortisol, and increased the phosphorylation of AKT in the NCI-H295R cells. Our data present evidence for a functional role of orexin-A in human adrenocortical cells through the $\mathrm{OX}_{1}$ receptor-stimulated AKT signaling pathway.

\section{Materials and methods}

Reagents. Orexin-A was obtained from Sigma (St. Louis, MO, USA). RPMI-1640 medium and fetal bovine serum were purchased from Gibco (Grand Island, NY, USA). The AKT inhibitor, PF-04691502, was purchased from Selleck Chemicals LLC (Houston, TX, USA). The $\mathrm{OX}_{1}$ receptorspecific antagonist, SB334867, was obtained from Tocris Bioscience (Minneapolis, MN, USA). The cell proliferation enzyme-linked immunosorbent assay (ELISA) BrdU colorimetric kit was purchased from Roche Diagnostics (Penzberg, Germany). Total-AKT polyclonal antibody (ab8805), phosphoAKT (s473) polyclonal antibody (ab8932) and $\mathrm{OX}_{1}$ receptor antibody (ab68718) were obtained from Abcam (Cambridge, UK). The Cortisol Express EIA kit was purchased from Alpco (Paris, France). $\beta$-actin antibody (C4; sc-47778) and 3 $\beta$-HSD antibody (37-2; sc-100466) were obtained from Santa Cruz Biotechnology, Inc., Santa Cruz, CA, USA.

Cell culture. Human NCI-H295R adrenocortical cells were obtained from the American Type Culture Collection (Manassas, VA, USA) and maintained in RPMI-1640 medium supplemented with $10 \%$ (wt/vol) fetal bovine serum, L-glutamine, penicillin $(50 \mu \mathrm{g} / \mathrm{ml})$ and streptomycin $(100 \mu \mathrm{g} / \mathrm{ml})$. The cells were grown in a humidified atmosphere containing $5 \% \mathrm{CO}_{2}$ at $37^{\circ} \mathrm{C}$. Prior to the experiments, the cells were grown in petri dishes in serum-free medium for $24 \mathrm{~h}$.The following day, the cells $\left(4 \times 10^{3}\right.$ cells/well in 96 -well plates, $5 \times 10^{5}$ cells/well in 6-well plates) were treated with various concentrations of orexin-A $\left(0,10^{-10}, 10^{-8}\right.$ and $\left.10^{-6} \mathrm{M}\right)$, or $10^{-6} \mathrm{M}$ orexin-A with either SB334867 or PF-04691502, or a combination of both.

Cell proliferation assays. The adrenocortical NCI-H295R cells were seeded $\left(2 \times 10^{3}\right.$ cells/well) in 96-well plates and cultured for $24 \mathrm{~h}$. To synchronize the cell cycle, the cells were serumdeprived for $24 \mathrm{~h}$ and then treated with the test agents for a further $24 \mathrm{~h}$. BrdU incorporation into DNA was measured using the Cell Proliferation ELISA BrdU colorimetric kit (Roche Diagnostics). The cells were incubated with BrdU fresh medium at $37^{\circ} \mathrm{C}$ and $5 \% \mathrm{CO}_{2}$ for $12 \mathrm{~h}$ and fixed with $200 \mu \mathrm{l}$ of fixative/denaturing solution for $30 \mathrm{~min}$ at room temperature. Peroxidase-conjugated BrdUrd antibody was then added to each well followed by incubation for $1 \mathrm{~h}$. After washing thoroughly, the bound peroxidase-conjugated BrdUrd antibody was quantified with peroxidase substrate tetramethylbenzidine. Finally the BrdUrd absorbance was measured at $440 \mathrm{~nm}$ using an ELISA plate reader (BioTek Instruments, Winooski, VT, USA). A control without cells was used to measure the background absorbance of the medium and was subtracted from the results.

Cortisol measurements. For cortisol release experiments, the NCI-H295R cells were cultured in 6-well plates until the cells were at approximately $80-85 \%$ confluence. The cells were serum starved overnight, then washed and incubated in fresh serum-free medium containing various concentrations of orexin-A and the different inhibitors for $24 \mathrm{~h}$. At the end of the incubation period, the supernatant was removed and snap-frozen immediately in liquid nitrogen until the cortisol measurements were taken. Cortisol levels were assessed using the ELISA kit according to the manufacturer's instructions.

Total RNA preparations and reverse transcription quantitative polymerase chain reaction ( $R T-q P C R)$. Total RNA was extracted from the NCI-H295R cells using TRIzol reagent (Invitrogen, Carlsbad, CA, USA). The mRNA expression of $\mathrm{OX}_{1}$ receptor and $\mathrm{OX}_{2}$ receptor was detected by real-time PCR using TaqMan reagents (Takara, Otsu, Japan). The following specific primers were used: $\mathrm{OX}_{1}$ receptor forward, 5'-TGC GGC CAA CCC TAT CAT CTA-3' and reverse, 5'-ACC GGC TCT GCA AGG ACAA-3'; OX 2 receptor forward, 5'-ATC GCA GGG TAT ATC ATC GTG TTC-3' and reverse, 5'-TGA CTG TCC TCA TGT GGT GGT TC-3'; 3 $\beta$-HSD forward, 5'-AGC AAA AAG ATG GCC GAG AA-3' and reverse, 5'-GGC ACA AGT ATG CAA TGT GCC-3'. As an internal control for reverse transcription (RT) and reaction efficiency, the amplification of glyceraldehyde-3-phosphate dehydrogenase (GAPDH) mRNA was carried out in parallel for each sample. The following specific primers were used: GAPDH forward, 5'-GGC ACA GTC AAG GCT GAG AAT G-3' and reverse, 5'-ATG GTG GTG AAG ACG CCA GTA-3'. The PCR reactions were carried out using the following conditions: $95^{\circ} \mathrm{C}$ for $30 \mathrm{sec}$, then 40 cycles of $95^{\circ} \mathrm{C}$ for $5 \mathrm{sec}, 60^{\circ} \mathrm{C}$ for $30 \mathrm{sec}$, and $95^{\circ} \mathrm{C}$ for $15 \mathrm{sec}$. All primers and TaqMan probes specific to $\mathrm{OX}_{1}$ receptor, $\mathrm{OX}_{2}$ receptor, $3 \beta$-HSD and $\mathrm{GAPDH}$ were 
designed using Primer Premier 5.0 software (Premier Biosoft International, Palo Alto, CA, USA).

Protein preparations and western blot analysis. The NCI-H295R cells were washed with cold phosphate-buffered saline (PBS) and harvested in RIPA buffer containing protease inhibitors. The cell lysates were incubated on ice for $30 \mathrm{~min}$ and were collected and centrifuged at $12,000 \mathrm{x}$ g for $10 \mathrm{~min}$ at $4^{\circ} \mathrm{C}$. The supernatants were collected and mixed with $5 \mathrm{X}$ loading buffer, then denatured by boiling for $10 \mathrm{~min}$. The samples were separated by sodium dodecyl sulfate-polyacrylamide gel (SDS-PAGE) and transferred onto PVDF membranes at $60 \mathrm{~V}$ for $2.5 \mathrm{~h}$ in transfer buffer containing $20 \mathrm{mM}$ Tris, $150 \mathrm{mM}$ glycine and $20 \%$ methanol. The membranes were incubated in non-fat dry milk for $120 \mathrm{~min}$ at room temperature, and then washed 3 times with TBST for $30 \mathrm{~min}$, then incubated with primary antibody against $\mathrm{OX}_{1}$ receptor at a 1:250 dilution, phospho/ total-AKT at a 1:1,000 dilution or antibody against 3 $\beta$-HSD at a 1:1,000 dilution in TBST overnight at $4^{\circ} \mathrm{C}$. The membranes were washed and incubated with a secondary antibody (source: rabbit) for $1.5 \mathrm{~h}$ at room temperature, and then washed 3 times with TBST for $30 \mathrm{~min}$. Protein was visualized using the ECL method. Band densities were measured using Quantity One software.

Statistical analysis. The results are expressed as the means \pm standard error of the mean (SEM) and differences between the means were analyzed by one-way analysis of variance (ANOVA). A value of $\mathrm{P} \leq 0.05$ was considered to indicate a statistically significant difference.

\section{Results}

Orexin-A receptor expression in NCI-H295R cells. RT-qPCR assays demonstrated that $\mathrm{OX}_{1}$ receptor mRNA was expressed in the NCI-H295R cells (Fig. 1A). However, $\mathrm{OX}_{2}$ receptor mRNA was not detectable under the same conditions (data not shown). Orexin-A $\left(10^{-10}, 10^{-8}\right.$ and $\left.10^{-6} \mathrm{M}\right)$ induced a significant increase in the mRNA and protein levels of $\mathrm{OX}_{1}$ receptor in a dose-dependent manner (Fig. 1). Treatment with orexin-A increased $\mathrm{OX}_{1}$ receptor protein expression in the NCI-H295R cells, an increase that was dependent upon the concentration of orexin-A, with $10^{-6} \mathrm{M}$ of orexin-A exerting the most potent effect (Fig. 1B). This increase in expression was attenuated in the presence of $10^{-6} \mathrm{M}$ SB334867, a high-affinity, $\mathrm{OX}_{1}$ receptorspecific, non-peptide antagonist (Fig. 1B).

Orexin-A enhances the proliferation of NCI-H295R cells. To determine the effects of orexin-A on cell survival, as well as the involvement of the AKT signaling pathway in the effects of orexin-A in the NCI-H295R cells, we employed BrdU incorporation assay to examine cell proliferation. The NCI-H295R cells were treated with various concentrations $(0$, $10^{-10}, 10^{-8}$ and $10^{-6} \mathrm{M}$ ) of orexin-A; the promoting effects on cell proliferation were dose-dependent. Concentrations of $10^{-6}$ and $10^{-8} \mathrm{M}$ of orexin-A led to a 0.8 - and 0.6 -fold increase in cell proliferation, respectively. However, these effects were partly blocked when the cells were treated with $10^{-6} \mathrm{M}$ orexin-A and the $\mathrm{OX}_{1}$ receptor antagonist, SB334867 $\left(10^{-6} \mathrm{M}\right)$, or the AKT antagonist, $\mathrm{PF}-04691502\left(10^{-6} \mathrm{M}\right)$, as well as with a combina-
A

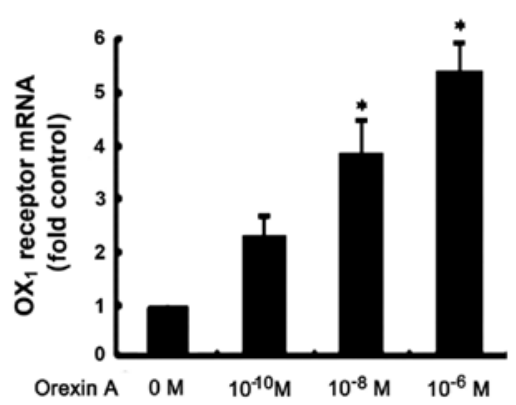

B
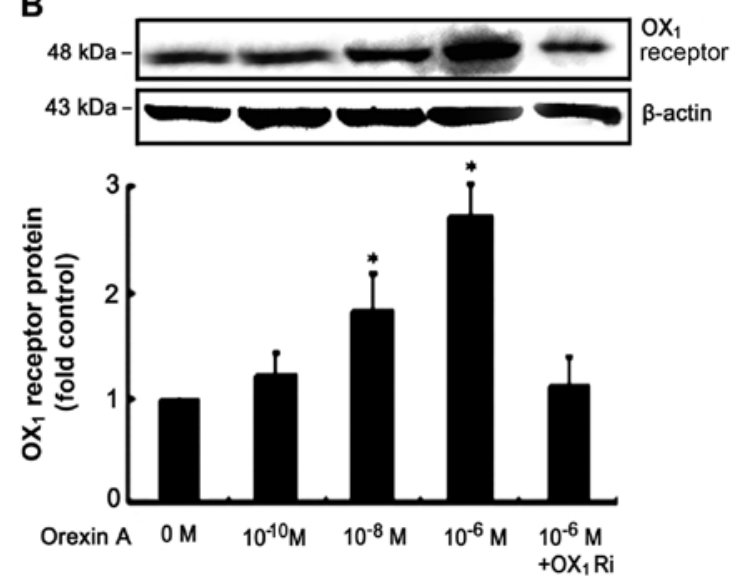

Figure 1. Orexin-A receptor expression in NCI-H295R cells. The cells were exposed to orexin-A at concentrations of $0,10^{-10}, 10^{-8}$ and $10^{-6} \mathrm{M}$ for $24 \mathrm{~h}$. Another treatment group consisted of $10^{-6} \mathrm{M}$ orexin-A in the presence of the orexin receptor type $1\left(\mathrm{OX}_{1}\right)$ receptor antagonist, $\mathrm{SB} 334867\left(\mathrm{OX}_{1} \mathrm{Ri}\right)$ $\left(10^{-6} \mathrm{M}\right)$. The expression of $\mathrm{OX}_{1}$ receptor $\mathrm{mRNA}(\mathrm{A})$ and protein (B) was measured by RT-qPCR and western blot analysis. Data are presented as the means \pm standard error of the mean (SEM) based on triplicate determinations from a representative experiment. Asterisks indicate significant differences compared to the controls ( $\mathrm{P}<0.05)$.

tion of both antagonists. Taken together, these data suggest that AKT participates in the orexin-A-induced stimulation of the proliferation of NCI-H295R cells (Fig. 2).

Orexin-A induces cortisol secretion from NCI-H295R cells. To determine whether the production of the cortisol is affected in orexin-A-stimulated NCI-H295R cells, cortisol levels in the culture medium were assessed using an ELISA kit. The dosedependent effects of orexin-A on the cortisol content in the medium were determined from the cell culture supernatants. The effects of $10^{-6}$ and $10^{-8} \mathrm{M}$ orexin-A reached statistical significance, increasing cortisol secretion by 1.0 - and 0.5 -fold, respectively compared to the controls (untreated cells). This affect was blocked in the presence of PF-04691502 $\left(10^{-6} \mathrm{M}\right)$, SB334867 $\left(10^{-6} \mathrm{M}\right)$ and the combination of both antagonists (Fig. 3).

Effects of orexin-A on 3 $\beta$-HSD mRNA and protein expression. Follwoing starving overnight in serum-free medium, the NCI-H295R cells were incubated with various concentrations $\left(0,10^{-10}, 10^{-8}\right.$ and $\left.10^{-6} \mathrm{M}\right)$ of orexin-A, and the cells were then treated with $10^{-6} \mathrm{M}$ orexin-A and the $\mathrm{OX}_{1}$ receptor antagonist, SB334867 $\left(10^{-6} \mathrm{M}\right)$, or the AKT antagonist, PF-04691502 $\left(10^{-6} \mathrm{M}\right)$, or a combination of both antagonists. Treatment with orexin-A increased the mRNA and protein expression 


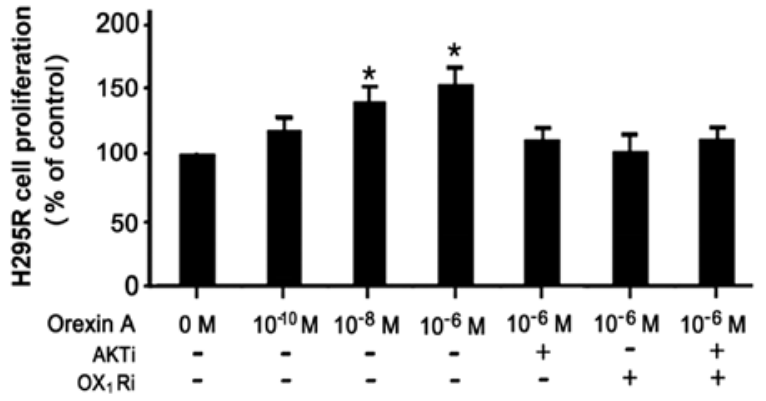

Figure 2. Orexin-A enhanced the proliferation of NCI-H295R (H295R) cells via stimulation of the AKT signaling pathway. Cells were exposed to orexin-A at concentrations of $10^{-10}, 10^{-8}$ and $10^{-6} \mathrm{M}$ for 24 or $48 \mathrm{~h}$ in the presence or absence

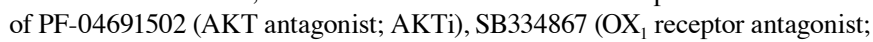
$\mathrm{OX}_{1} \mathrm{Ri}$ ), or a combination of both. Proliferation was determined by BrdU assay. Data are presented as the means \pm standard error of the mean (SEM) based on quadruplicate determinations from a representative experiment. Asterisks indicate significant differences when compared to the controls ( $\mathrm{P}<0.05)$.

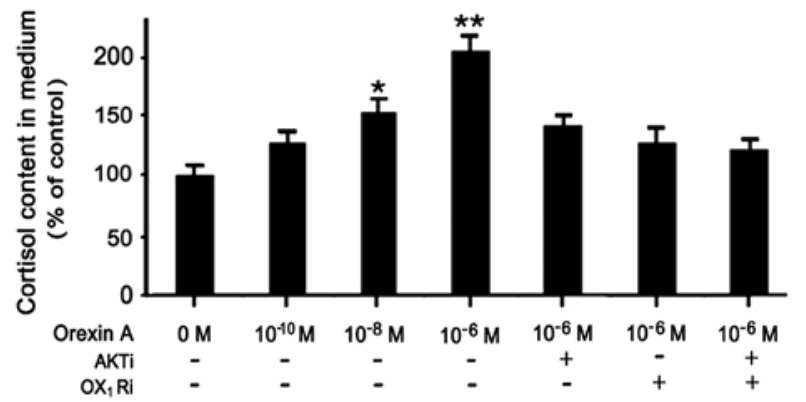

Figure 3. Orexin-A induces cortisol secretion from NCI-H295R cells. Cells were exposed to orexin-A at concentrations of $0,10^{-10}, 10^{-8}$ and $10^{-6} \mathrm{M}$ for $24 \mathrm{~h}$. Cells were cultured with $10^{-6} \mathrm{M}$ orexin- $\mathrm{A}$ for $24 \mathrm{~h}$ in the presence or absence of PF-04691502 (AKT antagonist; AKTi), SB334867 (OX receptor antagonist; $\mathrm{OX}_{1} \mathrm{Ri}$ ) or a combination of both antagonists. Cortisol content was assessed using an enzyme-linked immunosorbent assay (ELISA) kit. Data are presented as the means \pm standard error of the mean (SEM) based on triplicate determinations from a presentative experiment. Asterisks indicate significant differences compared to the controls ( $\left(\mathrm{P}<0.05\right.$ and $\left.{ }^{* *} \mathrm{P}<0.01\right)$.

levels of $3 \beta-H S D$ in the NCI-H295R cells, an increase that was dependent on the concentration of orexin-A, with $10^{-6} \mathrm{M}$ of orexin-A exerting the most potent effect. Concentrations of $10^{-6} \mathrm{M}$ and $10^{-8} \mathrm{M}$ orexin-A led to a 2.1- and 2.4-fold increase in the mRNA levels, respectively (Fig. 4A). As regards protein expression, $10^{-6} \mathrm{M}$ orexin- $\mathrm{A}$ and $10^{-8} \mathrm{M}$ orexin-A induced a 1.8- and 1.2-fold increase in expression, respectively compared to the controls (Fig. 4B). This increase was attenuated in the presence of $10^{-6} \mathrm{M} \mathrm{SB} 334867$ or $10^{-6} \mathrm{M}$ PF-04691502, or the combination of both antagonists.

Orexin-A signals through the AKT pathway. To determine wether the orexin-A-stimulation of NCI-H295R cells induces the activation of AKT, the NCI-H295R cells were stimulated with various concentrations $\left(0,10^{-6}, 10^{-8}\right.$ and $\left.10^{-10} \mathrm{M}\right)$ of orexinA. The data demonstrated a specific increase in the levels of phospo-AKT in the NCI-H295R cells treated with $10^{-6}$ and $10^{-8} \mathrm{M}$ orexin-A, increasing by $0.7-$ and 0.45 -fold, respectively, compared to the untreated controls (Fig. 5). The levels of total AKT, however, remained unaltered by treatment. In addition, the relative increase in AKT activation in response to orexin-A was abolished by treatment with AKT antagonist

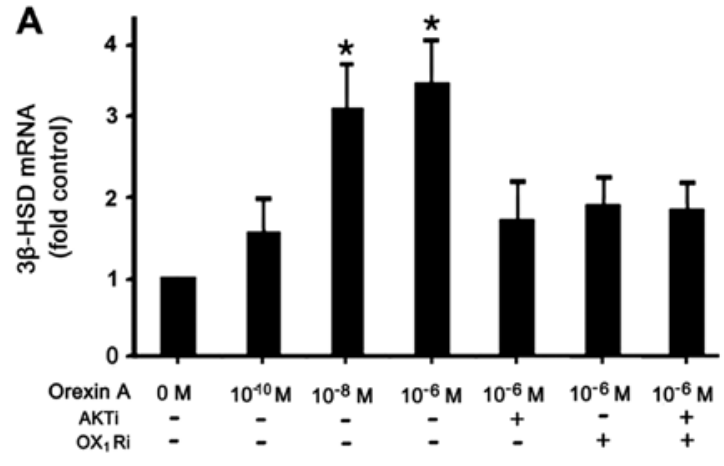

B
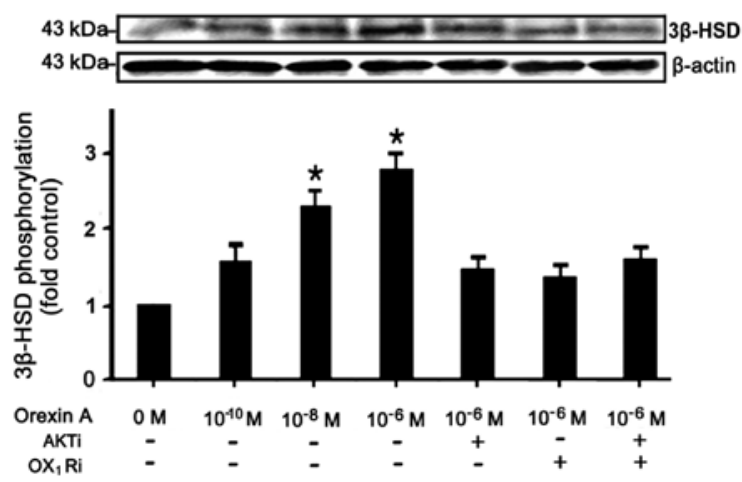

Figure 4. Effects of orexin-A on $3 \beta$-hydroxysteroid dehydrogenase ( $3 \beta$-HSD) mRNA and protein expression. Cells were exposed to orexin-A at concentrations of $0,10^{-6}, 10^{-8}$ and $10^{-10} \mathrm{M}$ for $24 \mathrm{~h}$. In addition, a separate group of cells was treated with $10^{-6} \mathrm{M}$ orexin-A in the presence of the $10^{-6} \mathrm{M}$ SB334867 $\left(\mathrm{OX}_{1}\right.$ receptor antagonist; $\mathrm{OX}_{1} \mathrm{Ri}$ ) or $10^{-6} \mathrm{M}$ PF-04691502 (AKT antagonist; AKTi), or a combination of both antagonists. The expression of $3 \beta-\mathrm{HSD}$ mRNA (A) and protein (B) was measured by RT-qPCR and western blot analysis. Data are presented as the means \pm standard error of the mean (SEM) based on quadruplicate determinations from a representative experiment. Asterisk indicate significant differences as compared to the controls $\left({ }^{*} \mathrm{P}<0.05\right)$.

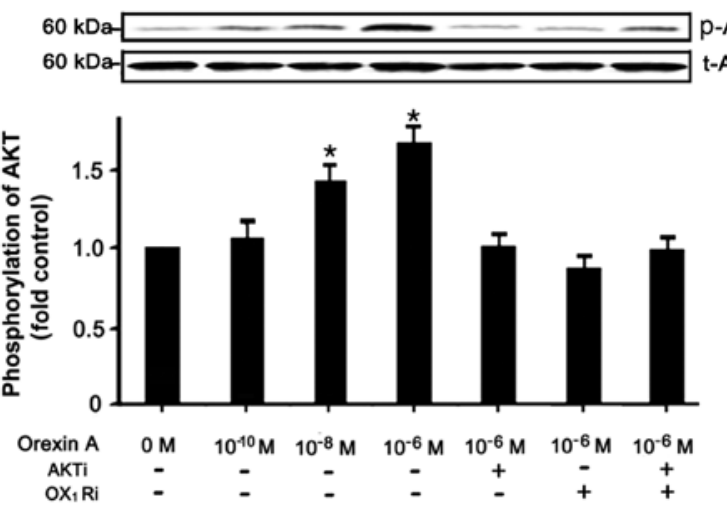

Figure 5. Orexin-A signals through the AKT pathway. Cells were stimulated with orexin-A at concentrations of $0,10^{-6}, 10^{-8}$ and $10^{-10} \mathrm{M}$ for $20 \mathrm{~min}$, in the presence of PF-04691502 (AKT antagonist; AKTi; $10^{-6} \mathrm{M}$ ), SB334867 $\left(\mathrm{OX}_{1}\right.$ receptor antagonist; $\left.\mathrm{OX}_{1} \mathrm{Ri} ; 10^{-6} \mathrm{M}\right)$ or the combination of both. Protein activation was measured by western blot analysis. Autophosphorylation of AKT was evaluated along with the total protein activation. Total AKT protein expression was used as an internal control for equal protein loading. Data are presented as the means \pm standard error of the mean (SEM) based on quintuplicate determinations from a representative experiment. Asterisks indicate significant differences compared to the controls ( $\mathrm{P}<0.05)$.

(PF-04691502, 10-6 M), OX 1 receptor antagonist (SB334867, $10^{-6} \mathrm{M}$ ), as well as the combination of both antagonsits (Fig. 5). 
Above all, these data suggest that the regulation of the AKT signaling pathway is intimately associated with the orexin-Astimulated NCI-H295R cell survival through the $\mathrm{OX}_{1}$ receptor.

\section{Discussion}

Studies have indicated an association between the hypocretin/ orexin system and the HPA axis on a central, as well as peripheral level (7). In this study, we dertermined the effects of orexin-A on the expression of $\mathrm{OX}_{1}$ receptor and the proliferation of human adrenocortical cells. Consistent with the study by Blanco et al (28), we did not observe the expression of $\mathrm{OX}_{2}$ receptor in the NCI-H295R cells. Furthermore, we found a marked increase in cortisol production and $3 \beta$-HSD expression following the stimulation of the NCI-H295R cells with orexin-A, that was associated with an increased activity of AKT. This finding indicates that another signaling pathway, the AKT pathway, partly regulates the survival and functions of adrenocortical cells stimulated with orexin-A through the $\mathrm{OX}_{1}$ receptor.

Previous studies addressing the effects of orexins on adrenal function focused on the effects of the HPA axis. One of the first in vivo studies described an increase in both adrenocorticotropic hormone (ACTH) and corticosterone plasma levels 1-2 $\mathrm{h}$ following a single systemic administration of orexin-A in rats, while orexin-B had no stimulating effect (9). Other studies clearly demonstrated an additional direct action of orexins on the adrenal cortex without the involvement of the HPA axis $(7,12)$. Orexin-A enhances the production of mineralocorticoids, glucocorticoids and androgens in the adrenal glands (29). Furthermore, studies have demonstrated the important role of orexin-A in adrenocortical cell proliferation $(8,12)$. However, data on whether orexins regulate the growth of carcinoma cells are inconlcusive. Certain studies have found that orexins promote the growth of cancer cells $(8,10)$, athough others have shown inhibitory effects $(30,31)$. The different cell types used may be the reason for these conflicting results. Consistent with previous studies, we found that orexin-A stimulated NCI-H295R cell proliferation $(8,10)$ and promoted the release of cortisol in a dose-dependent manner, while the effects were blunted by co-treatment with the $\mathrm{OX}_{1}$ receptor antagonist, SB334867. The synthesis of glucocorticoids in human adrenal glands is achieved by the selective expression of some steroid-synthesizing enzymes, such as $3 \beta$-HSD. As previously reported, the selective upregulation of $3 \beta$-HSD mRNA expression following prolonged stimulation with orexins indicated the existence of a specific pathway for the transcriptional regulation of orexins (14). In this study, we found the highest cortisol synthesis rate after $24 \mathrm{~h}$ of treatment with orexin-A, possibly due to the stimulation of the expression of $3 \beta-\mathrm{HSD}$ and the proliferation of adrenocortical cells. This was consistent with the results of a previous study by Wenzel et al, who demonstrated that orexins increased the expression of steroidogenic enzymes at the transcriptional level and that orexins played a role in the long-term regulation of adrenal steroid production (14).

As is well known, among mechanisms controlling the cell growth and survival, the PI3K signaling pathway is often activated. The serine/threonine kinase AKT, acting downstream of PI3K signaling, is a key regulator of multiple survival routes (32-37). Previous studies focused on the effects of orexin-A on the MAPK pathway $(6,25)$. Göncz et al $(38)$ found that orexin-A modulated glucagon secretion and gene expression through the PI3K/AKT-dependent pathway in clonal pancreatic A-cells (InR1-G9 cells). They found an increase in the phosphorylation of AKT and phosphoinositide-dependent kinase-1 (PDK-1) proteins in response to treatment with orexin-A $\left(10^{-5} \mathrm{M}\right)$ in InR1-G9 cells. Our study demonstrated that orexin-A $\left(10^{-10}\right.$ to $\left.10^{-6} \mathrm{M}\right)$ stimulated NCI-H295R cell proliferation and promoted the release of cortisol and increased the expression of $3 \beta$-HSD. In addition we observed a specific increase in the levels of phospho-AKT in the NCI-H295R cells treated with $10^{-6}$ and $10^{-8} \mathrm{M}$ orexin-A. The levels of total AKT, however, remained unaltered by treatment. The increase in AKT phosphorylation may be involved in the regulation of the expression of $3 \beta$-HSD. However, these effects were partly blocked by co-treatment with the $\mathrm{OX}_{1}$ receptor antagonist, SB334867, or the AKT antagonist, $\mathrm{PF}-04691502$, as well as with the combination of both antagonists. With respect to the concentration of orexin-A, it is possible that the cell type may be an important factor contributing to the physiological effects of orexin-A. Further studies are required in order to further determine to what extent the cell type plays a role in the effects of orexin-A. Taken together, these data suggest that orexin-A stimulates $3 \beta$-HSD expression and cortisol production in human adrenocortical cells through the $\mathrm{OX}_{1}$ receptor mediated through the AKT pathway.

In conclusion, we demonstrate that the AKT signaling pathway is involved in the orexin-A stimulated increase in the synthesis of cortisol in human adrenocortical cells. Although this interaction of orexins with adrenocortical cell functions, particularly with glucocorticoid production, has now bee established, more comprehensive and specific mechanisms remain to be elucidated to clarify the nature of the signaling pathway. On the whole, orexins, together with leptin, may comprise a counter-regulatory system that controls body weight and energy homeostasis through the regulation of adrenocortical steroid production.

\section{Acknowledgements}

This study was supported by the National Natural Science Foundation of China (grant nos. 30872724, 81071460 and 81271996). We are thankful to the China Medical University Affiliated Hospital Laboratory Center for kindly providing the necessary equipment.

\section{References}

1. de Lecea L, Kilduff TS, Peyron C, Gao X, Foye PE, Danielson PE, Fukuhara C, Battenberg EL, Gautvik VT, Bartlett FS II, Frankel WN, van den Pol AN, Bloom FE, Gautvik KM and Sutcliffe JG: The hypocretins: hypothalamus-specific peptides with neuroexcitatory activity. Proc Natl Acad Sci USA 95: 322-327, 1998.

2. Heinonen MV, Purhonen AK, Mäkelä KA and Herzig KH: Functions of orexins in peripheral tissues. Acta Physiol (Oxf) 192: 471-485, 2008

3. Matsuki T and Sakurai T: Orexins and orexin receptors: from molecules to integrative physiology. Results Probl Cell Differ 46: 27-55, 2008.

4. Sakurai T1, Amemiya A, Ishii M, Matsuzaki I, Chemelli RM, Tanaka H, Williams SC, Richardson JA, Kozlowski GP, Wilson S, Arch JR, Buckingham RE, Haynes AC, Carr SA, Annan RS, McNulty DE, Liu WS, Terrett JA, Elshourbagy NA, Bergsma DJ and Yanagisawa $M$ : Orexins and orexin receptors: a family of hypothalamic neuropeptides and $\mathrm{G}$ protein-coupled eceptors that regulate feeding behavior. Cell 92: 573-585, 1998. 
5. Voisin T, Rouet-Benzineb P, Reuter N and Laburthe M: Orexins and their receptors: structural aspects and role in peripheral tissues. Cell Mol Life Sci 60: 72-87, 2003.

6. Kagerer SM and Jöhren O: Interactions of orexins/hypocretins with adrenocortical functions. Acta Physiol (Oxf) 198: 361-371, 2010.

7. Malendowicz LK, Hochol A, Ziolkowska A, Nowak M, Gottardo L and Nussdorfer GG: Prolonged orexin administration stimulates steroid-hormone secretion, acting directly on the rat adrenal gland. Int J Mol Med 7: 401-404, 2001.

8. Malendowicz LK, Jedrzejczak N, Belloni AS, Trejter M, Hochol A and Nussdorfer GG: Effects of orexins A and B on the secretory and proliferative activity of immature and regenerating rat adrenal glands. Histol Histopathol 16: 713-717, 2001

9. Malendowicz LK, Tortorella C and Nussdorfer GG: Orexins stimulate corticosterone secretion of rat adrenocortical cells, through the activation of the adenylate cyclase-dependent signaling cascade. J Steroid Biochem Mol Biol 70: 185-188, 1999.

10. Mazzocchi G, Malendowicz LK, Gottardo L, Aragona F and Nussdorfer GG: Orexin A stimulates cortisol secretion from human adrenocortical cells through activation of the adenylate cyclase-dependent signaling cascade. J Clin Endocrinol Metab 86: 778-782, 2001.

11. Nanmoku T, Isobe K, Sakurai T, Yamanaka A, Takekoshi K, Kawakami Y, Goto K and Nakai T: Effects of orexin on cultured porcine adrenal medullary and cortex cells. Regul Pept 104: 125-130, 2002.

12. Spinazzi R, Rucinski M, Neri G, Malendowicz LK and Nussdorfer GG: Preproorexin and orexin receptors are expressed in cortisol-secreting adrenocortical adenomas, and orexins stimulate in vitro cortisol secretion and growth of tumor cells. J Clin Endocrinol Metab 90: 3544-3549, 2005.

13. Ziolkowska A, Spinazzi R, Albertin G, Nowak M, Malendowicz LK, Tortorella $\mathrm{C}$ and Nussdorfer GG: Orexins stimulate glucocorticoid secretion from cultured rat and human adrenocortical cells, exclusively acting via the $\mathrm{OX}_{1}$ receptor. J Steroid Biochem Mol Biol 96: 423-429, 2005.

14. Wenzel J, Grabinski N, Knopp CA, Dendorfer A, Ramanjaneya M, Randeva HS, Ehrhart-Bornstein M, Dominiak P and Jöhren O: Hypocretin/orexin increases the expression of steroidogenic enzymes in human adrenocortical NCI H295R cells. Am J Physiol Regul Integr Comp Physiol 297: R1601-R1609, 2009.

15. Hayes HM Jr and Wilson GP: Hormone-dependent neoplasms of the canine perianal gland. Cancer Res 37: 2068-2071, 1977.

16. Sauer LA, Chapman JC and Dauchy RT: Topology of 3 betahydroxy-5-ene-steroid dehydrogenase/delta 5-delta 4-isomerase in adrenal cortex mitochondria and microsomes. Endocrinology 134: 751-759, 1994.

17. Zhao HF, Labrie C, Simard J, de Launoit Y, Trudel C, Martel C, Rhéaume E, Dupont E, Luu-The V, Pelletier G and Labriel F: Characterization of rat 3 beta-hydroxysteroid dehydrogenase/ delta 5- delta 4 isomerase c DNAs and differential tissue specific expression of the corresponding mRNAs in steroidogenic and peripherial tissues. J Biol Chem 266: 583-593, 1991.

18. van Blitterswijk WJ and Verheij M: Anticancer mechanisms and clinical application of alkylphospholipids. Biochim Biophys Acta 1831: 663-674, 2013.

19. Fu L, Kim YA, Wang X, Wu X, Yue P, Lonial S, Khuri FR and Sun SY: Perifosine inhibits mammalian target of rapamycin signaling through facilitating degradation of major components in the mTOR axis and induces autophagy. Cancer Res 69: 8967-8976, 2009.

20. Hay N and Sonenberg N: Upstream and downstream of mTOR. Genes Dev 18: 1926-1945, 2004.

21. Richardson CJ, Schalm SS and Blenis J: PI3-kinase and TOR: PIKTORing cell growth. Semin Cell Dev Biol 15: 147-159, 2004.
22. Hsieh AC, Truitt ML and Ruggero D: Oncogenic AKTivation of translation as a therapeutic target. Br J Cancer 105: 329-336, 2011.

23. Sale EM and Sale GJ: Protein kinase B: signalling roles and therapeutic targeting. Cell Mol Life Sci 65: 113-127, 2008.

24. Blandino-Rosano M, Chen AY, Scheys JO, Alejandro EU, Gould AP, Taranukha T, Elghazi L, Cras-Méneur C and Bernal-Mizrachi E: mTORC1 signaling and regulation of pancreatic $\beta$-cell mass. Cell Cycle 11: 1892-1902, 2012.

25. Ramanjaneya M, Conner AC, Chen J, Kumar P, Brown JE, Jöhren O, Lehnert H, Stanfield PR and Randeva HS: Orexinstimulated MAP kinase cascades are activated through multiple G-protein signalling pathways in human H295R adrenocortical cells: diverse roles for orexins A and B. J Endocrinol 202: 249-261, 2009.

26. Ramanjaneya M, Conner AC, Chen J, Stanfield PR and Randeva HS: Orexins stimulate steroidogenic acute regulatory protein expression through multiple signaling pathways in human adrenal H295R cells. Endocrinology 149: 4106-4115, 2008.

27. Rainey WE, Saner K and Schimmer BP: Adrenocortical cell lines. Mol Cell Endocrinol 228: 23-38, 2004.

28. Blanco M, García-Caballero T, Fraga M, Gallego R, Cuevas J, Forteza J, Beiras A and Diéguez C: Cellular localization of orexin receptors in human adrenal gland, adrenocortical adenomas and pheochromocytomas. Regul Pept 104: 161-165, 2002.

29. Payne AH and Hales DB: Overview of steroidogenic enzymes in the pathway from cholesterol to active steroid hormones. Endocr Rev 25: 947-970, 2004.

30. Rouet Benzineb P, Rouyer Fessard C, Jarry A, Avondo V, Pouzet $\mathrm{C}$, Yanagisawa M, Laboisse $\mathrm{C}$, Laburthe $\mathrm{M}$ and Voisin $\mathrm{T}$ : Orexins acting at native $\mathrm{OX}(1)$ receptor in colon cancer and neuroblastoma cells or at recombinant OX(1) receptor suppress cell growth by inducing apoptosis. J Biol Chem 279: 45875-45886, 2004

31. Biegańska K, Sokołowska P, Jöhren O and Zawilska JB: Orexin A suppresses the growth of rat C6 glioma cells via a caspasedependent mechanism. J Mol Neurosci 48: 706-712, 2012.

32. Alessandro R and Kohn EC: Signal transduction targets in invasion. Clin Exp Metastasis 19: 265-273, 2002.

33. Sachdev P, Jiang YX, Li W, Miki T, Maruta H, Nur-E-Kamal MS and Wang LH: Differential requirement for Rho family GTPases in an oncogenic insulin-like growth factor-I receptor-induced cell transformation. J Biol Chem 276: 26461-26471, 2001.

34. Nguyen KT, Wang WJ, Chan JL and Wang LH: Differential requirements of the MAP kinase and PI3 kinase signaling pathways in Src- versus insulin and IGF-1 receptors-induced growth and transformation of rat intestinal epithelial cells. Oncogene 19: 5385-5397, 2000.

35. Sachdev LP, Zeng and Wang LH: Distinct role of phosphatidylinositol 3-kinase and Rho family GTPases in Vav3-induced cell transformation, cell motility, and morphological changes. J Biol Chem 277: 17638-17648, 2002.

36. Nguyen KT, Zong CS, Uttamsingh S, Sachdev P, Bhanot M, Le MT, Chan JL and Wang LH: The role of phosphatidylinositol 3-kinase, rho family GTPases, and STAT3 in Ros-induced cell transformation. J Biol Chem 277: 11107-11115, 2002.

37. Arboleda MJ, Lyons JF, Kabbinavar FF, Bray MR, Snow BE, Ayala R, Danino M, Karlan BY and Slamon DJ: Overexpression of AKT2/protein kinase Bbeta leads to up-regulation of beta1 integrins, increased invasion, and metastasis of human breast and ovarian cancer cells. Cancer Res 63: 196-206, 2003.

38. Göncz E, Strowski MZ, Grötzinger C, Nowak KW, Kaczmarek P, Sassek M, Mergler S, El-Zayat BF, Theodoropoulou M, Stalla GK, Wiedenmann B and Plöckinger U: Orexin-A inhibits glucagon secretion and gene expression through a Foxo1-dependent pathway. Endocrinology 149: 1618-1626, 2008. 